\title{
Conservative management for ceramic laminate veneers using digital workflow: case
}

\section{report with 18-month follow-up}

Tratamento conservador para laminados cerâmicos usando fluxo de trabalho digital: relato de caso com acompanhamento de 18 meses

Manejo conservador de laminados cerámicos mediante flujo de trabajo digital: reporte de un caso con seguimiento de 18 meses

Fabrício Daniel Finotti Guarnieri

ORCID: https://orcid.org/0000-0003-2290-3123 Araçatuba School of Dentistry, Brazil E-mail: fabriciodfg@me.com Wirley Gonçalves Assunção ORCID: https://orcid.org/0000-0002-8903-0737 Araçatuba School of Dentistry, Brazil E-mail: wirley.assuncao@unesp.br

Jéssica Monique Lopes Moreno ORCID: https://orcid.org/0000-0002-8808-4872 Araçatuba School of Dentistry, Brazil E-mail: jessica_morenoo@ hotmail.com

Fernanda de Souza e Silva Ramos ORCID: https://orcid.org/0000-0003-2222-2424 Araçatuba School of Dentistry, Brazil E-mail: fer_ramos_fer@hotmail.com

Lara Maria Bueno Esteves ORCID: https://orcid.org/0000-0002-4032-6502 Araçatuba School of Dentistry, Brazil E-mail: 1m.esteves@unesp.br

André Luiz Fraga Briso

ORCID: https://orcid.org/0000-0002-6126-1760 Araçatuba School of Dentistry, Brazil E-mail: andre.briso@unesp.br

Ticiane Cestari Fagundes

ORCID: https://orcid.org/0000-0002-3418-0498 Araçatuba School of Dentistry, Brazil E-mail: ticiane.fagundes@unesp.br

\begin{abstract}
Introduction: Esthetics dental treatments involving ceramic laminate veneers can obtain optimal results through detailed considerations with respect to teeth preparations, gingival margins and esthetic factors. Objectives: This case report aims to present a conservative management for ceramic conservative preparation associated with the digital workflow for ceramic laminates, with 18-month follow-up. Case Report: Patient complaining of a child smile due to diastemas in the anterior region. The planning and design of the smile was carried out using a software (Keynote, Ceramill Mind). After molding and printing a 3D model, a mock-up was performed, which was used as a surgical guide for the performance of gingivoplasty. The conservative dental preparation was then performed, with cervical enamel preservation. The ceramic laminates were made after molding and scanning the model, using the CAD/CAM system and cemented on the dental surface. It was observed that there was an increase in gingival quality and thickness, achieving esthetics, color and marginal stability, after 18 months of follow-up. Conclusion: The conservative preparation technique associated with the digital workflow allowed the manufacture of thin ceramic laminate veneer, promoting stability of esthetics and periodontal health after 18 months.
\end{abstract}

Keywords: CAD / CAM; Ceramics; Dental esthetics; Dental veneer.

\section{Resumo}

Introdução: Tratamentos dentários estéticos envolvendo lentes de cerâmica podem obter ótimos resultados por meio de considerações detalhadas a respeito do preparo dos dentes, das margens gengivais e fatores estéticos. Objetivos: Este relato de caso clínico tem por objetivo apresentar uma técnica de preparo conservador associado ao fluxo de trabalho digital para laminados cerâmicos, com acompanhamento de 18 meses. Relato do Caso: A paciente queixava- 
se de sorriso com aspecto infantil devido aos diastemas presentes na região anterior. O planejamento e design do sorriso foram realizados com o auxílio de softwares (Keynote, Ceramill Mind). Após moldagem e impressão de modelo 3D, foi realizado o mock-up, sendo este também utilizado como guia cirúrgico para a realização da gengivoplastia. Em seguida, fez-se o preparo dentário com preservação do esmalte cervical. Os laminados cerâmicos foram confeccionados após moldagem e escaneamento do modelo, utilizando o sistema CAD / CAM, sendo cimentados sobre a superfície dentária. Observou-se que houve aumento da qualidade e espessura gengival, alcançando estética, cor e estabilidade do nível gengival marginal após 18 meses de acompanhamento clínico. Conclusão: A técnica de preparo conservador associado ao fluxo de trabalho digital permitiu a confecção de laminados cerâmicos ultrafinos, promovendo estabilidade da estética, função e da saúde periodontal após 18 meses.

Palavras-chave: CAD / CAM; Cerâmica; Estética dentária; Coroa dentária.

\section{Resumen}

Introducción: Los tratamientos estéticos dentales con laminados de cerámica pueden obtener resultados óptimos mediante consideraciones detalladas con respecto a la preparación de los dientes, los márgenes gingivales y los factores estéticos. Objetivos: Este caso clínico tiene como objetivo presentar una técnica de preparación conservadora asociada al flujo de trabajo digital para laminados cerámicos, con un seguimiento de 18 meses. Caso clínico: El paciente se quejaba de sonrisa infantil por diastemas en la región anterior. La planificación y el diseño de la sonrisa se llevaron a cabo con la ayuda de un software (Keynote, Ceramill Mind). Luego de moldear e imprimir el modelo 3D, se realizó una mock-up, que se utilizó como guía quirúrgica para la realización de la gingivoplastia. En seguida, la preparación dental se realizó de forma conservadora, con preservación del esmalte cervical. Los laminados cerámicos se realizaron después de moldear y escanear el modelo, utilizando el sistema CAD / CAM, siendo cementado sobre la superficie dental. Se observó un aumento del grosor y la calidad gingival, alcanzando la estética, el color y la estabilidad del nivel gingival marginal a los 18 meses de seguimiento clínico. Conclusión: La técnica de preparación conservadora asociada al flujo de trabajo digital permitió la fabricación de laminados cerámicos ultras delgados, promoviendo la estabilidad de la estética y la salud periodontal a los 18 meses.

Palabras clave: CAD / CAM; Cerámica; Estética dental; Corona dental.

\section{Introduction}

The demand for esthetics in dental treatments involving ceramic laminate veneers can obtain optimal results through detailed considerations with respect to teeth preparations, gingival margins and esthetic factors. Esthetic rehabilitation through ceramic laminate veneers are currently applied with minimal wear (Farias-Neto et al., 2019). The digital workflow allows a dynamic documentation of the smile trough 2D/3D digital smile designs that will help in the treatment using ceramic laminate veneers (Stanley, Paz, Miguel \& Cristão, 2018).

Ceramic laminate veneers have shown excellent esthetic results and predictable longevity of the treatment, while composite veneers can be considered as a good conservative option, but with less durability (Alothman \& Bamasoud, 2018). In this context, ceramic laminate veneers, can be defined as extremely thin ceramic fragments, ranging from 0.2 to $0.5 \mathrm{~mm}$, with excellent optical properties (Da Cunha, Pedroche, Gonzaga \& Furuse, 2014). It is considered one of the most conservative treatments for smile rehabilitation, as it requires minimal tooth preparation (Morita et al., 2016). These laminates have presented high survival rates ranging from 87 to $100 \%$ after 1 to 11 -year such as demonstrate in a review based on prospective and retrospective studies (Alothman \& Bamasoud, 2018). Regarding the ceramic materials, clinical studies have shown that feldspathic, lithium disilicate and leucite-reinforced glass ceramics are the materials that present more satisfactory result in long follow-ups (Beier, Kapferer, Burtscher \& Dumfahrt 2012; Edelhoff et al., 2018; Fradeani, Redemagni \& Corrado, 2005; Layton \& Clarke, 2013; Layton \& Walton, 2012)

Ceramic-based restorations can be presented in different forms, according to the technique used in all fabrications which include stratified base system, pressable glass base system, and computer-aided design/computer-aided manufacturing (CAD/CAM) system (Sampaio et al., 2019). Various factors may influence the marginal discrepancies and consequently the longevity of ceramic restorations; such as: type of finishing lines, choice of restorative materials and procedures during cementation (Ranganathan, Dhanraj \& Ashish 2017). 
Futhermore, one of the reports of complications associated with ceramic laminates is the apical migration of the gingival margin, which may be related to the periodontal biotype (Walton, 2014). Thus, one of the main causes of periodontal migration is the subgingival location of prosthetic restorations, which, when not properly adapted, cause greater inflammation, even offering better esthetic results (Su, Gonzalez-Martin, Weisgold \& Lee, 2010). With this, trying to minimize unexpected results, a minimal finishing line can be applied and the outline of the soft tissue contour can be determined by the contours of the laminates (Farias-Neto et al., 2019).

With the advent of fully digital workflow, those failures can be avoided by controlling the amount of wear, aligning the gingival margin and performing minimally invasive and predictable preparations, favoring both the work of the operator and treatment longevity (Stanley, Paz, Miguel \& Cristão, 2018; Gurel et. al., 2012).

Thus, the constant rise of materials, techniques and equipment, the need to control wear on the dental structure and the condition of the patient's periodontal have added greater expression and impelled the clinician to pursue new techniques that support the precision of the work. Therefore, the present case report aims to present a conservative management for preparation associated with the digital workflow for ceramic laminates, with an 18-month follow-up.

\section{Methodology}

This case study is according to Imburgia (2016) because this methodology focuses on a specific case and details involved in the esthetic treatment. The patient sought a private clinic for esthetic dental care, in the city of São Paulo - SP. After completing the initial photos and treatment plan, she signed the Live and Informed Consent Form. Thus, in addition to the description of the clinical case report, this paper presents and discusses the general aspects about its importance, indication, applicability and conservative management.

\section{Results}

A female patient aged 25 years sought treatment with the main complaint of a child smile, characterized by diastema and small teeth (Figure 1). For the treatment planning, initial photos and impressions were taken with polyvinyl siloxane material (PVS- Virtual Ivoclar Vivadent, Schaan, Liechtenstein). Cranio-maxillary transfers were taken and the plaster models were mounted on a semi-adjustable articulator (A7 Plus Bioart, São Carlos, SP, Brazil). 
Figure 1. Extraoral pretreatment condition of the patient, facial view showing diastemas and lack of good proportion and harmony of the smile; demonstrating the main complaint of a child smile.

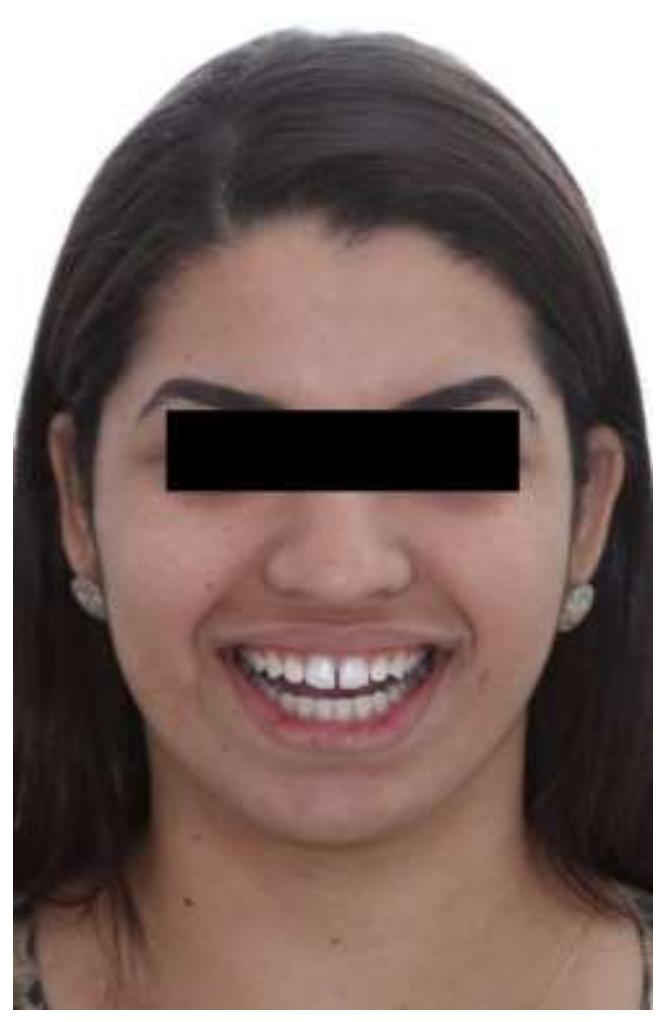

Fonte: Authors (2016).

The planning and design of the smile were carried out with the aid of a software (Keynote, Apple Inc., CupertinoCalifórnia, USA) to better meet patient expectations, improve communication with the dental laboratory, and also obtain a 2D planning design.

The plaster models (Dentona AG, Dortmund Deutschland) were scanned (AmannGirbach MAP400), loaded onto a software (Ceramill Mind-AmannGirrbach, Austria), and the model chosen as a reference to copy the natural morphology was selected (ZTM Norbert Wichnalek, Augsburg, Deutschland) (Figures 2A, 2B, 2C). 
Figure 2. (A) Image of model, choice by the patient, used for natural morphology (B) Removing gingival tissue to use the same model in the next step (C) Customized 3D virtual design created by the superimposed of the model from natural morphology above the model from patient.

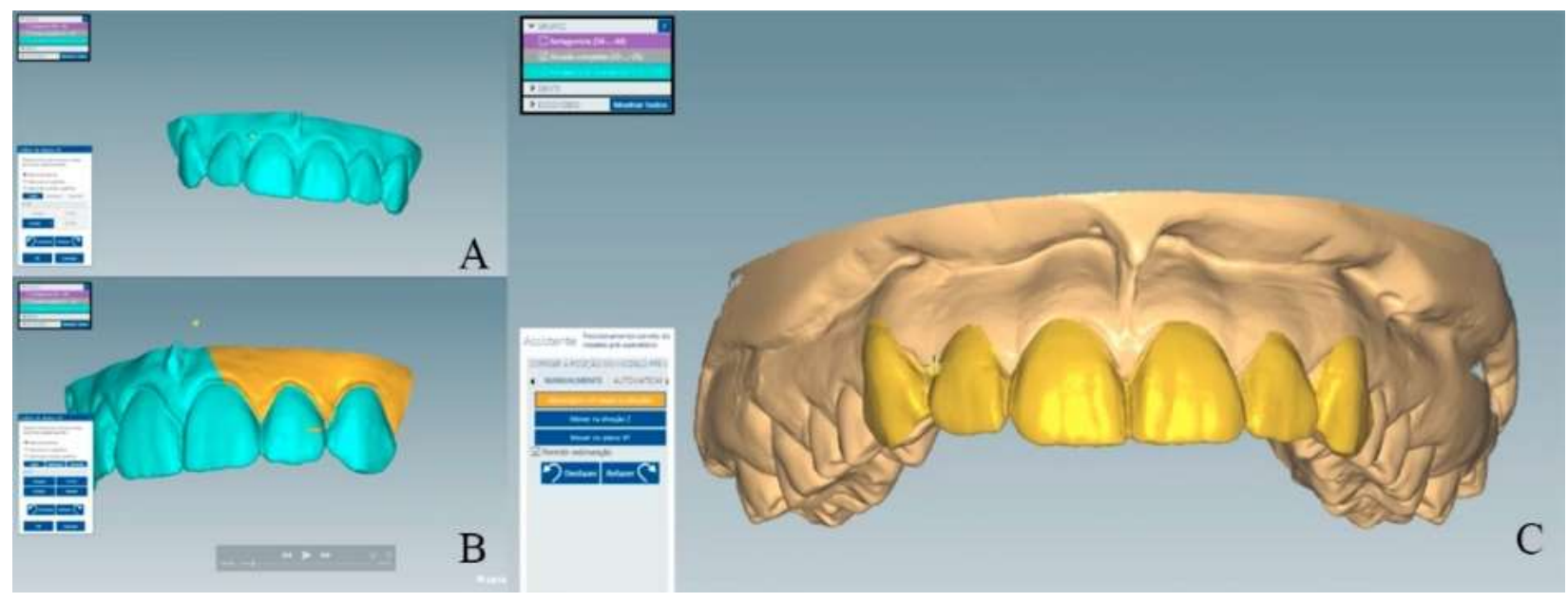

Fonte: Authors (2016).

The 3D model obtained was elaborated in the software following the sequence: selection of the teeth involved in the project, delimitation of the margins based on the 2D project for the digital wax-up, including the gingival area to be corrected. Subsequently, the external reference model was trimmed to remove the gums and it was adjusted and scaled to fit the patient's maxillary arch (the scale was made maintaining the proportions of the natural model without distorting the 3D mesh, keeping the natural algorithm). In the sequence, the tool to connect the 3D drawing to the margins was used and some distortions were generated, especially in the cervical area. This is a recurring problem related to almost every CAD software and can be minimized by adapting the 3D design as close as possible to the desired final position of the digital wax-up. These procedures can minimize the software's need to do many calculations to create the proper emergence profile and therefore the designer will have to make minor adjustments to the final 3D design. Once the project was complete, a model was generated for 3D printing directly from the software (Ceramill Mind, Ceramill Mind-AmannGirrbach, Austria) in a standard triangular language (stl) format.

The digitally waxed model was then printed on a 3D printer (Envisiontec, Dearborn, Michigan, USA) at 50-micron resolution, and the mock-up was fabricated with a silicone matrix (Virtual - Ivoclar Vivadent AG, Schaan, Liechtenstein) filled with bis-acrylic resin (Systemp-Ivoclar Vivadent AG, Schaan, Liechtenstein). In Figure 3A the 3D model with digital waxing overlay the patient's image, and in Figure 3B the aspect of the simulation immediately after the excess bis-acrylic resin was removed with a sharp instrument and the inhibited layer was removed by rubbing an $70 \%$ alcohol-wet gauze. The texture and morphology of the reference model were maintained. 
Figure 3. (A) Integration of the $2 \mathrm{D}$ smile design with the $3 \mathrm{D}$ digital wax up in specific software, that can observe the proportions; (B) Aspect of the mock up allowing the previous visualization of the final result of the treatment.
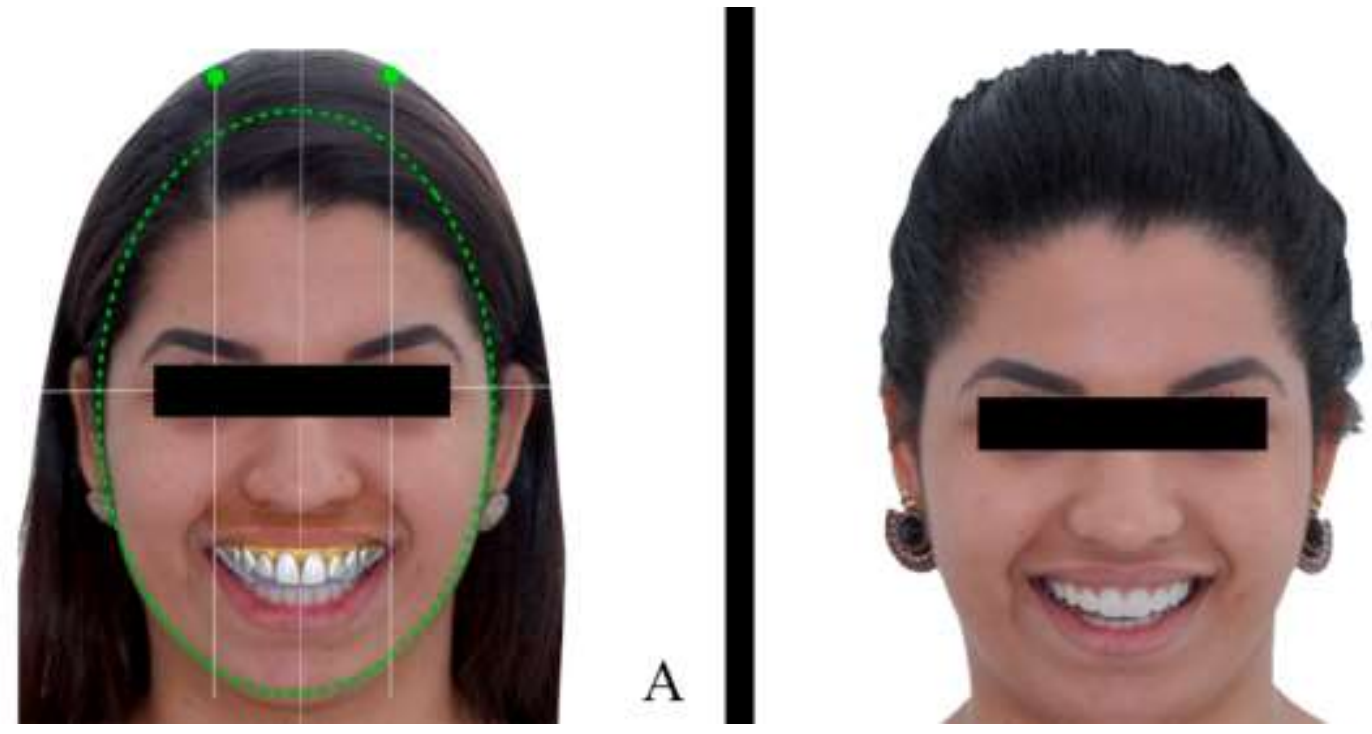

Fonte: Authors (2016).

After the patient's approval the clinical procedures were initiated. The mock-up was used as a surgical guide to perform gingivoplasty, simplifying the process and allowing the clinician to follow exactly the initial planning (Chu, Tan, Stappert \& Tarnow, 2009; Gurrea \& Bruguera2014) (Figures 4A, 4B). A small incision was made using an external bevel technique.

Figure 4. (A) Mock-up been used as a surgical guide and gingivoplasty was performed; (B) Immediate result after gingivoplasty and mock up removal.
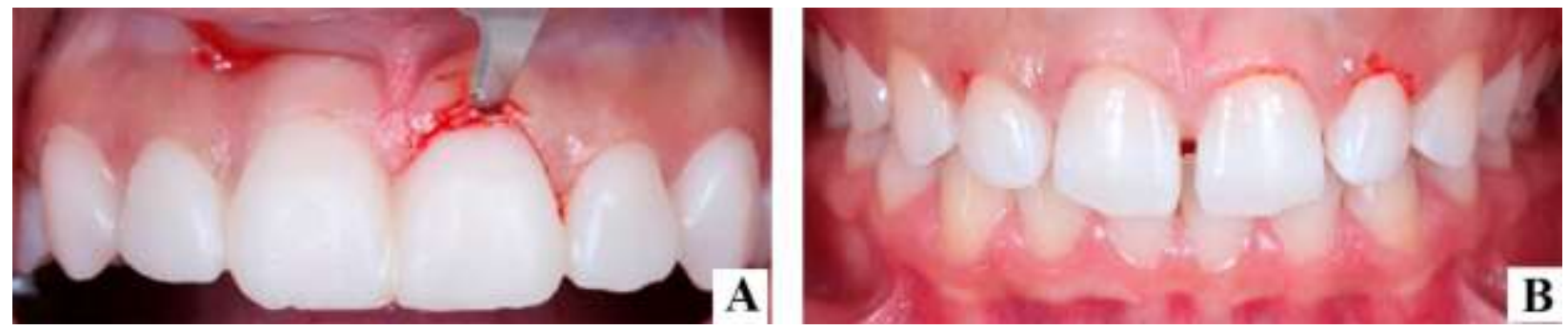

Fonte: Authors (2016).

Tooth preparation followed a conservative approach, as regards preservation of enamel in the cervical region, where its thickness is reduced, ranging from 0.3 to $0.5 \mathrm{~mm}$. Wear was performed with a tapered and cylindrical diamond bur (2135 KG Sorensen, SP, Brazil), reducing retentive areas without removing proximal contacts. The incisal regions were regularized only to have the proper shape and inclination, removing the sharp areas to avoid stress areas under the ceramic, the cervical margin was established at the gingival level. Then, an extra fine diamond bur (2135 FF - KG Sorensen, Sao Paulo, SP, Brazil) and abrasive discs (Soft-Lex Pop-On, 3M ESPE, St. Paul, MN, USA) were used for polishing. For this same purpose, a piezoelectric device (CVdentus, Sao Jose dos Campos, SP, Brazil) with a conical cylindrical diamond bur (CR1) with 30\% power was used (Figure 5A, 5B, 5C). 
Figure 5. (A) Preparation with a tapered-cylindrical diamond tip; (B) Piezo electrical round diamond tip to refine gingival margins; (C) Aspect of the conservative preparations after polishing.

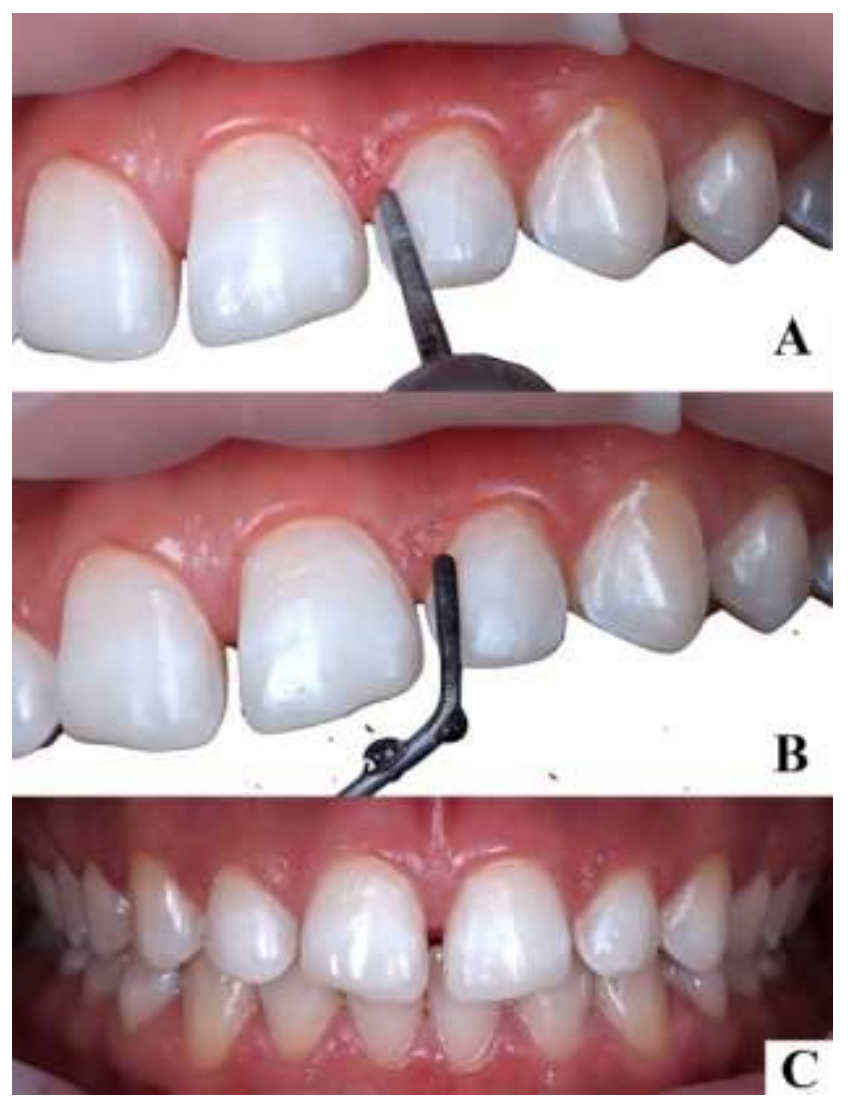

Fonte: Authors (2016).

After the teeth preparations, an impression was taken with PVS material (Virtual, Ivoclar Vivadent AG, Schaan, Liechtenstein) using a double-cord retraction, numbers 000 and 00 (Ultrapack, Ultradent Products, Inc., South Jordan, EUA). The plaster models were obtained (Dentona AG, Dortmund Deutschland type IV). The models were then digitalized and the ceramic laminate veneers were designed, using the diagnostic wax-up as a reference to copy the final restorations.

The milling of the ceramic was performed (CEREC MCXL inlab Sirona, Bensheim, Deutschland), and the veneers were adjusted in the rigid plaster model. The ceramic used was a leucite-reinforced glass ceramic (CAD Empress Ivoclar Vivadent AG, Schaan, Liechtenstein). The ceramic laminate veneers were then made up and polished following the manufacturer's directions.

Then, the veneers were etched with 5\% hydrofluoric acid for 20 seconds and were washed with an air-water spray (Belli, Guimarães, Filho \& Vieira, 2010), then a silane coupling agent (Monobond Plus Ivoclar Vivadent AG, Schaan, Liechtenstein) was applied to the internal face of each veneer.

The teeth were isolated with a rubber dam, etched with 35\% phosphoric acid for 30 seconds and washed with an airwater spray for 60 seconds. The teeth surfaces were then dried with a gentle air spray. A thin single layer of adhesive (Excite $\mathrm{F}$ Ivoclar Vivadent AG, Schaan, Liechtenstein) was applied to the dental enamel and the air spray was used for 30 seconds. Cement was applied to the ceramic laminate veneers (Variolink Veneer +1 , Ivoclar Vivadent AG, Schaan, Liechtenstein) and they were cemented to the teeth. The excess cement was removed and with a brush before photo curing. Light curing (Kerr GMBH, Biberach, Deutschland) was done tooth by tooth for 30 seconds on each surface (vestibular and palatal). Remaining 
excess cement was removed with a sharp instrument and the interfaces between tooth and veneers were polished (Figures 6A, $6 \mathrm{~B}, 6 \mathrm{C})$.

Figure 6. (A) Isolation of the teeth using rubber dam and clamps; (B) Fit check of laminate veneer with correct marginal adaptation; (C) Bonding procedure and cementation of the two central incisors.
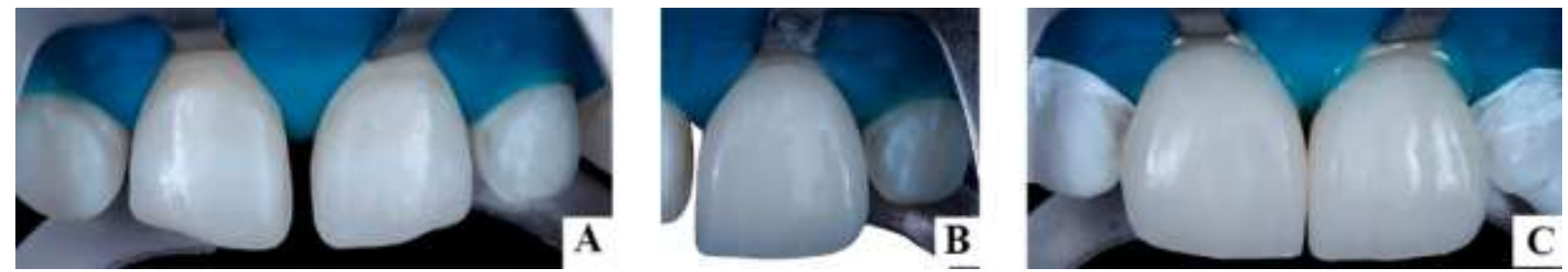

Fonte: Authors (2016).

Figures 7A and 7B show the similarity of the final aspect of rehabilitation to the project developed through the selection of natural teeth.

Figure 7. (A) Aspect of the final project in specific software; (B) Intra oral aspect of the final ceramic laminated veneers immediately after bonding procedure.

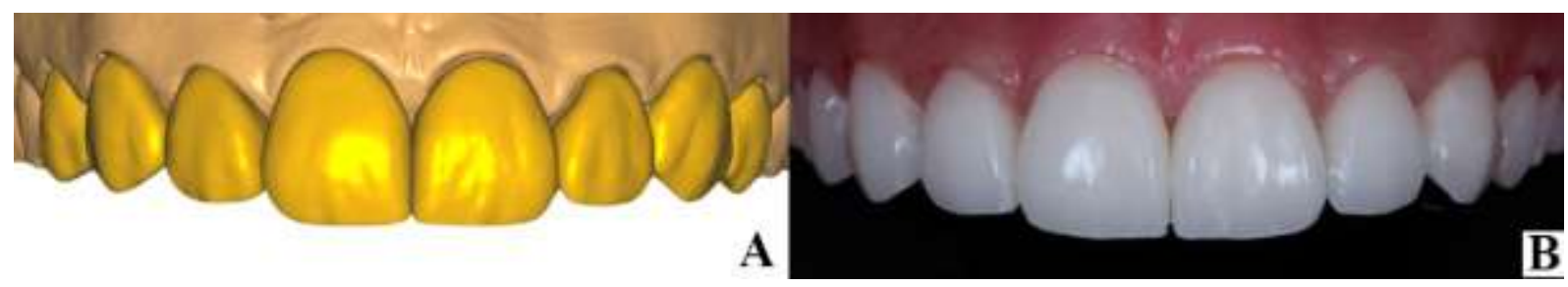

Fonte: Authors (2016).

Figures $8 \mathrm{~A}$ and $8 \mathrm{~B}$ show the completed treatment and at 18-month follow-up respectively, showing the gingival health and natural appearance provided by the technique used. 
Figure 8. (A) Close up of the gingival marginal area of the two superior central incisors 7 days after bonding procedures; (B) Close up of the two superior central incisors after 18 months, demonstrating gingival health.
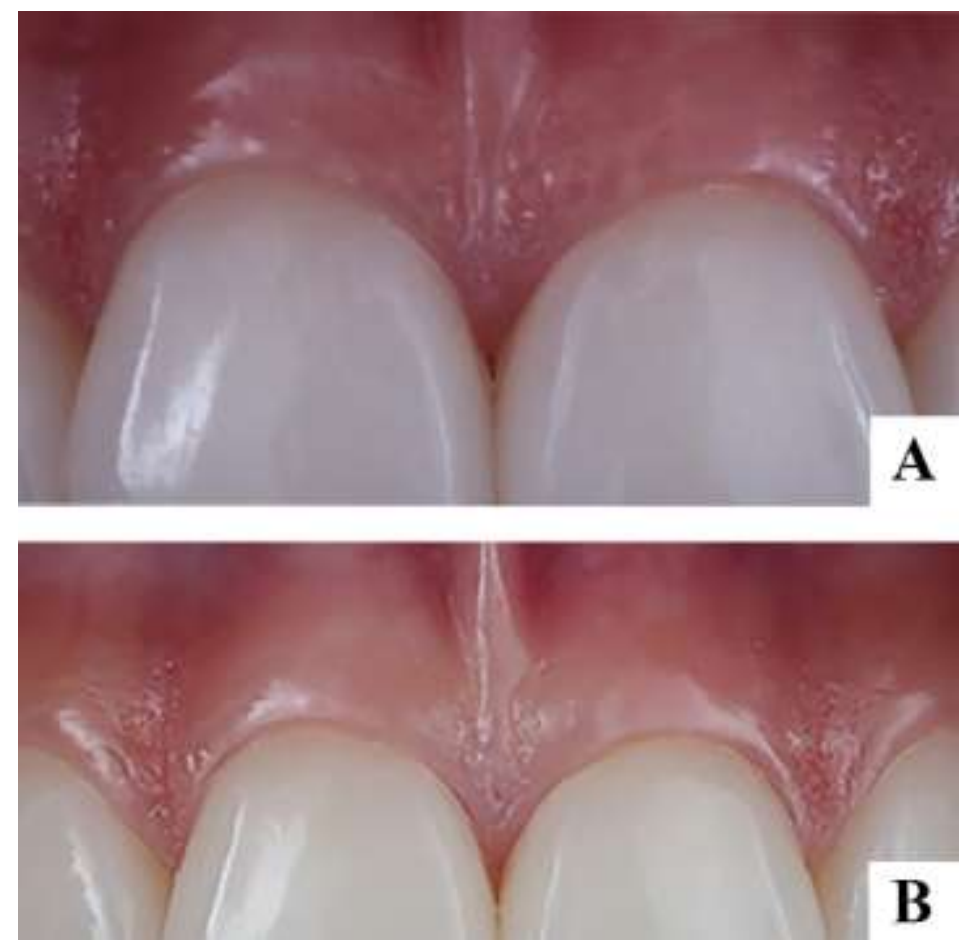

Fonte: Authors (2016).

Figure 9: Image from 18-month follow-up after cementation, it is possible to observe the esthetic facial proportion and a good gingival health

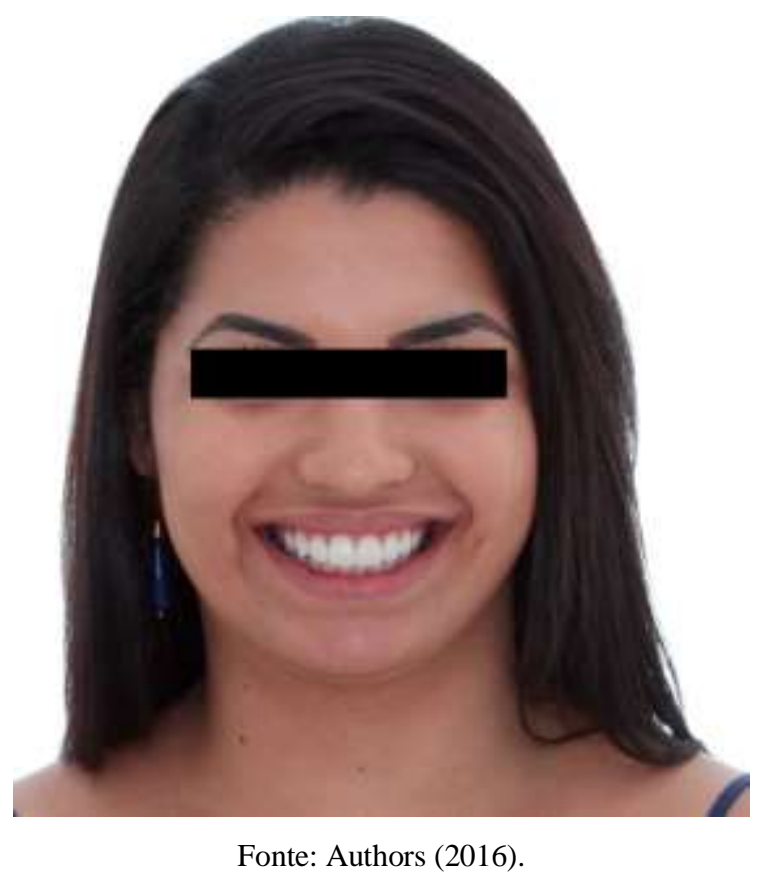

\section{Discussion}

The esthetic treatment of anterior teeth has always presented a challenge in clinical practice (Imburgia et al., 2016). Excellent esthetic results preserving the biological structures involved is one of main difficulties (Farias-Neto et al., 2019). 
Thus, the esthetic rehabilitation with a minimally invasive preparation associated with fine ceramics, increased predictability and safety, mainly for achieving the preservation of cervical enamel that directly influenced the adhesion process, promoting esthetic and functional durability (Haak et al., 2021).

The esthetic proportions derived from the mathematical exposition, also known as golden ratio, are clinically used to predict the width of each anterior tooth in order to reconstruct a natural profile that portrays a harmonious proportion (Kantrong, Traiveat \& Wongkhantee, 2019). Dental esthetics is not all about the white esthetics, gingiva also is of indispensable importance. (Patil \& Desai, 2013). The essentials of a smile involve the relationships among the teeth, the lip framework, and the gingival scaffold (Patil \& Desai, 2013).

The use of a 2D smile design associated with a 3D waxing, helps to identify disharmony on golden ratio in the superior central incisor, when planning to increase the mesio-distal width, the inciso-cervical height should be proportionally increased. The 3D model was covered on the $2 \mathrm{D}$ image, in which the golden ratio was performed, permitting real-time feedback on facial esthetics and any changes to the plan, which was not possible in the conventional planning (Lin et al., 2018; Silva et al., 2020). In this sense, the presence of a slight gum disproportion in anterior incisors could have been solved through biologically oriented preparation technique, which consists of extending the end of the preparation by up to $0.8 \mathrm{~mm}$ in the gingival sulcus (Serra-pastor et al. 2019). The second option would be to perform mild gingivoplasty (Su, Gonzalez-Martin, Weisgold \& Lee, 2010). Considering that the patient has a thin tissue biotype, as well as not needing osteotomy, gingivoplasty was chosen (Morita et al., 2016; Gresnigt et al., 2019; Álvaro \& Oliveira, 2016, Lindhe, \& Lang, 2018).This technique was performed by external bevel with the mock-up positioned, which permitted better visualization of the operative area and better assessment of the necessary tooth structure to be exposed.

The preparation of enamel is guided by three aspects: the need to increase the volume of the facial surface of the teeth, the color of the dental substrate and the insertion path for the ceramic restorations (Morita et al., 2016). In this case report, as the patient showed diastemas in the anterior region that required an increase in tooth volume, this was the factor that guided the preparation and enamel recontouring. Then, the teeth preparations were conservative and adjusted to the gingival level to ensure greater stability in the long term, improvement of the emergency profile, facilitate the maintenance of oral hygiene and create restorative longevity with a natural aspect (Gresnigt et al., 2019). The minimal preparation was also able to preserve the incisal margin, not overlapping (Hekimoglu, Anil \& Yalçin, 2004). A meta-analysis that evaluated the survival rates of preparation designs for ceramic veneers with and without incisal coverage showed $91 \%$ of success preserving this margin, contrasting with $88 \%$ to the other preparation (Albanesi et al., 2016). In this context, it is important to note that in the present case report, it was possible to conserve a large amount of dental structure, ensuring that the shape of the teeth remained unchanged, thus avoiding the need for temporary restorations or reports of dentinal sensitivity events (Morita et al., 2016).

Esthetic rehabilitation with ceramic laminates is being increasingly used as a way to preserve tooth structure, especially in young patients (Vanlıŏlu \& Kulak-Özkan, 2014). The use of ceramic laminate veneers with thickness below 0.5 $\mathrm{mm}$ requires an acid etching protocol performed with 5\% hydrofluoric acid for 20 seconds since this concentration and time reduce the potential of structure loss in the ceramic glass matrix. (Fabián, Regina Guenka \& De Goes 2018). The literature reports that $10 \%$ concentration of hydrofluoric acid can reach a depth of $0.4 \mathrm{~mm}$ when the is used for 60 seconds in the internal surface of ultra-fine ceramic laminate veneers (Fabián, Regina Guenka \& De Goes 2018).

The new concept of this paper also aims to demonstrate a digital workflow, which can provide new possibilities in dentistry, such as reduced clinical time and a higher level of predictability (Joda, Zarone \& Ferrari 2017). CAD/CAM systems can be more efficient in reproducing the diagnostic wax-up, since they have libraries of dental morphology available to the clinician or prosthetic. This advantage excludes manual reconstructions, preserving the desired esthetic and functional aspects of rehabilitation, maintaining accuracy proven to be similar to the impressions obtained with the PVS material (Joda, Zarone \& 
Ferrari 2017). The final design of ceramic laminates from the present case report followed the previously design, being printed on the CAD/CAM printer (Lin et al., 2018).

However, it is important to note that, this report presents limitations as the relatively high cost of the equipment, the need to develop new skills regarding digital workflow and change paradigms of daily practice. Besides, long-term follow-ups are extremely necessary to provide success for the treatment.

\section{Conclusion}

The use of conservative teeth management for ultra-fine ceramic laminate veneers using digital workflow allowed the treatment of this case presenting diastema in the anterior region. The stability of the gingival margin was achieved, promoting stability of esthetics and periodontal health after 18 months.

\section{References}

Alothman, Y., \& Bamasoud, M. S. (2018). The success of dental veneers according to preparation design and material type. Open Access Maced J Med Sci, 6 (12), 2402-2408.

Álvaro, N. L. A.; \& Oliveira, C. M. G. (2016) Gengivectomia e Gengivoplastia: Em Busca ao "Sorriso Perfeito". Braz J Periodontol, 27 (3), $30-36$.

Belli, R., Guimarães, J.C., Filho, A.M. \& Vieira, L.C. (2010). Post-etching cleaning and resin/ceramic bonding: microtensile bond strength and EDX analysis. J Adhes Dent; 12 (4), 295-303.

Chu, S., Tan, J., Stappert, C. \& Tarnow, D. (2009). Gingival zenith positions and levels of the maxillary anterior dentition. J Esthet Restor Dent, 21 (2), 113 120 .

Edelhoff, D., Prandtner, O., Saeidi, Pour, R., Liebermann, A., Stimmelmayr, M, \& Güth, J. F. (2018) Anterior restorations: The performance of ceramic veneers. Quintessence Int, 49 (2), 89-101.

Fabián M. G., Regina Guenka, P. D. \& De Goes, M. F. (2018). Effect of acid etching on tridimensional microstructure of etchable CAD/CAM materials. Dent Mater, 34 (6), 944-955.

Farias-Neto, A., de Medeiros, F. C. D., Vilanova, L., Chaves, M. S., \& de Araújo, J. J. F. B. (2019). Tooth preparation for ceramic veneers: when less is more. Int J Esthet Dent, 14 (2), 156-164.

Fradeani, M., Redemagni, M., \& Corrado, M. (2005). Porcelain laminate veneers: 6- to 12-year clinical evaluation--a retrospective study. Int J Periodontics Restorative Dent, 25 (1), 9-17.

Gresnigt, M. M. M., Cune, M. S., Jansen, K., van der Made, S. A. M., \& Özcan, M. (2019). Randomized clinical trial on indirect resin composite and ceramic laminate veneers: Up to 10-year findings. J Dent, 86, 102-109.

Gurel, G., Morimoto, S., Calamita, M. A., Coachman, C., \& Sesma, N. (2012) Clinical performance of porcelain laminate veneers: Outcomes of the aesthetic pre-evaluative temporary (APT) technique. Int J Periodontics Restorative Dent, 32 (6), 625-635.

Haak, R., Siegner, J., Ziebolz, D., Blunck, U., Fischer, S., Hajtó, J, et al. (2021) OCT evaluation of the internal adaptation of ceramic veneers depending on preparation design and ceramic thickness Dent Mater, 37(3), 423-431.

Hekimoglu, C., Anil, N., \& Yalçin, E. (2004). A microleakage study of ceramic laminate veneers by autoradiography: effect of incisal edge preparation. J Oral Rehabil, 31 (3), 265-270

Imburgia, M., Canale, A., Cortellini, D., Maneschi, M., Martucci, C., \& Valenti, M. (2016). Minimally invasive vertical preparation design for ceramic veneers. Int J Esthet Dent, 11 (4), 460-471.

Joda, T., Zarone, F., \& Ferrari, M. (2017). The complete digital workflow in fixed prosthodontics: a systematic review. BMC Oral Health, 17 (1), 2-9.

Kantrong, N, Traiveat, k., \& Wongkhantee, S. (2019). Natural upper anterior teeth display an increasing proportion in mesio-distal direction. J Clin Exp Dent, $11(10), 890-897$.

Layton, D. M., \& Clarke, M. (2013). A systematic review and meta-analysis of the survival of non-feldspathic porcelain veneers over 5 and 10 years. Int $J$ Prosthodont, 26 (2), 111-124.

Layton, D. M., \& Walton, T. R. (2012). The up to 21-year clinical outcome and survival of feldspathic porcelain veneers: accounting for clustering. Int J Prosthodont, 25 (6), 604-612.

Lindhe, J., \& Lang, N. P. (2018). Tratado de Periodontia Clínica e Implantologia Oral. Guanabara Koogan. (6a ed.).

Lin, W. S., Harris, B. T., Phasuk, K., Llop, D. R., \& Morton, D. (2018). Integrating facial scan, virtual smile design, and 3D virtual patient for treatment with CAD-CAM ceramic veneers: A clinical report. J Prosthet Dent, 119 (2), 200-205. 
Research, Society and Development, v. 10, n. 4, e7210413825, 2021

(CC BY 4.0) | ISSN 2525-3409 | DOI: http://dx.doi.org/10.33448/rsd-v10i4.13825

Morita, R. K., Hayashida, M. F., Pupo, Y. M., Berger, G., Reggiani, R. D., \& Betiol, E. A. (2016) Minimally Invasive Laminate Veneers: Clinical Aspects in Treatment Planning and Cementation Procedures Case Rep Dent, 13, 1839793.

Patil, V. A., \& Desai, M. H. (2013). Assessment of gingival contours for esthetic diagnosis and treatment: a clinical study. Indian J Dent Res, 24 (3), $394-395$.

Ranganathan, H., Ganapathy, D. M., \& Jain, A. R. (2017). Cervical and Incisal Marginal Discrepancy in Ceramic Laminate Veneering Materials: A SEM Analysis. Contemp Clin Dent, 8 (2), 272-278.

Sampaio, F. B. W. R., Özcan, M., Gimenez, T. C., Moreira, M. S. N. A., Tedesco, T. K., \& Morimoto, S. (2019). Effects of manufacturing methods on the survival rate of ceramic and indirect composite restorations: A systematic review and meta-analysis. J Esthet Restor Dent, 31 (6), $561-571$.

Serra-Pastor, B., Loi, I., Fons-Font, A., Solá-Ruíz, M. F., \& Agustín-Panadero, R. (2019). Periodontal and prosthetic outcomes on teeth prepared with biologically oriented preparation technique: a 4-year follow-up prospective clinical study. J Prosthodont Res, 63 (4), $415-420$.

Stanley, M., Paz, A. I., Miguel, I., \& Cristão, C. (2018). Fully digital workflow, integrating dental scan, smile design and CAD-CAM: case report. BMC Oral Health, 18(134)

Su, H., Gonzalez-Martin, O., Weisgold, A. \& Lee, E. (2010). Considerations of implant abutment and crown contour: critical contour and subcritical contour. Int $J$ Periodontics Restorative Dent, 30 (4), 335-343.

Vanlığlu, B. A., \& Kulak-Özkan, Y. (2014). Minimally invasive veneers: current state of the art. Clin Cosmet Investig Dent, 28 (6), $101-107$.

Walton, T. R. (2014). Making sense of complication reporting associated with fixed dental prostheses. Int J Prosthodont, 27 (2), $114-118$. 